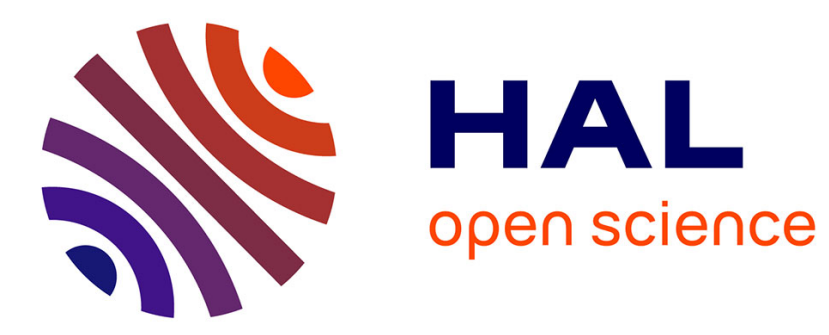

\title{
Start of Production in Low-Volume Manufacturing Industries: Disturbances and Solutions
}

\author{
Siavash Javadi, Jessica Bruch
}

\section{To cite this version:}

Siavash Javadi, Jessica Bruch. Start of Production in Low-Volume Manufacturing Industries: Disturbances and Solutions. IFIP International Conference on Advances in Production Management Systems (APMS), Sep 2015, Tokyo, Japan. pp.475-483, 10.1007/978-3-319-22756-6_58 . hal-01417562

\section{HAL Id: hal-01417562 \\ https://hal.science/hal-01417562}

Submitted on 15 Dec 2016

HAL is a multi-disciplinary open access archive for the deposit and dissemination of scientific research documents, whether they are published or not. The documents may come from teaching and research institutions in France or abroad, or from public or private research centers.
L'archive ouverte pluridisciplinaire HAL, est destinée au dépôt et à la diffusion de documents scientifiques de niveau recherche, publiés ou non, émanant des établissements d'enseignement et de recherche français ou étrangers, des laboratoires publics ou privés. 


\title{
Start of Production in Low-Volume Manufacturing Industries: Disturbances and Solutions
}

\author{
Siavash Javadi, Jessica Bruch \\ Mälardalen University, Design, Innovation and Engineering Department, Eskilstuna, Sweden \\ \{siavash.javadi, jessica.bruch\}@mdh. se
}

\begin{abstract}
Reducing disturbances during start of production of new products is of high importance to assure that products reach the market on-time with the intended quality and volume. Therefore, identification and elimination of sources of such disturbances is necessary. Since the literature about such disturbances in low-volume manufacturing industries are limited, this paper is aimed to identify the common sources of such disturbances and the possible solutions to mitigate them in low-volume manufacturing industries. A multiple-case study has been conducted to achieve this aim. The results show that main sources of disturbances are lack of opportunities to test and refine products, considering the production system "as is" and putting extensive focus on product functionality rather than its manufacturability. Moreover, using the knowledge and experiences from production of previous similar products is identified as a source of learning and compensation for lack of opportunities for test and refinement.
\end{abstract}

Keywords: product introduction, low-volume, industrialization, production start-up

\section{Introduction}

Manufacturing companies are forced to launch new products to the markets in shorter intervals due to factors such as globalization, rapidly emerging technologies and shorter product life cycles (Bellgran and Säfsten, 2010, Chryssolouris, 2006). Achieving shorter time to market protects the companies from crucial consequences such as losing markets and revenue and early outdating of the products (Hendricks and Singhal, 2008, Adler, 1995). However, the start of production is mainly characterized by high level of disturbances (Almgren, 2000, Nyhuis and Winkler, 2004) which usually lead to longer production cycle times (Apilo, 2003, Terwiesch and Bohn, 2001), lower production output (Juerging and Milling, 2005, Terwiesch et al., 2001) and lower quality of products (Almgren, 1999b, Nyhuis and Winkler, 2004, Terwiesch et al., 2001).

Most of such disturbances during the start of production can be prevented or mediated by preparatory activities before the start of production which are mostly carried out during the product introduction process (Säfsten and Aresu, 2002, Almgren, 1999c, Fjällström et al., 2009). The product introduction process is defined as the transition from product design to production and incorporate the activities which make the product manufacturable and prepare it for production (Bellgran and Säfsten, 2010, Johansen

adfa, p. 1, 2011.

(C) Springer-Verlag Berlin Heidelberg 2011 
and Björkman, 2002). Therefore, identification of sources of such disturbances at the start of production and eliminating or mitigating them by improving the product introduction process is necessary.

Improvement of the product introduction process in low-volume manufacturing industries requires solutions which are tailored to the requirements of such industries (Maffin and Braiden, 2001, Surbier et al., 2013). The literature about the sources of disturbances during the start of production of new products in low-volume manufacturing industries is very limited (Surbier et al., 2013). Therefore, the aim of this paper is to identify the sources of disturbances during the start of production of new products in low-volume manufacturing industries and to suggest general solutions for mitigating them.

The study focuses on disturbances related to product and production system not cover issues related to the external variables such as suppliers or customers. The research is based on a multiple-case study in a low-volume manufacturing company.

\section{Disturbances During Start of Production}

Sources of disturbances during the start of production have been studied mostly in form of case studies and in context of high-volume manufacturing industries (Surbier et al., 2013). Different researchers have studied and categorized the sources of disturbances in different ways such as Almgren (2000), Nyhuis and Winkler (2004) and Surbier et al. (2013). However, all of the named studies mention product and production system among main sources of disturbances. The product-related disturbances are summarizes by Surbier et al. (2013) as insufficient product specifications and lack of product maturity. The production system-related disturbances are described as lack of production process maturity, manufacturability of the product and product-production system fit (Surbier et al., 2013).

Most of these disturbances can be prevented by the activities carried out during the product introduction process. The product introduction process, also known as the industrialization process (Bellgran and Säfsten, 2010, Berg, 2007) is the closing and one of the key process of product development projects (Bellgran and Säfsten, 2010, Johansen and Björkman, 2002, Ruffles, 2000). During the product introduction process, product and production system are developed, tested, refined and adapted together (Fjällström et al., 2009, Ruffles, 2000).

The main phases of the product introduction process in high-volume manufacturing industries are conceptual study, development of engineering prototypes, pilot production, pre-series production and production ramp-up (Bellgran and Säfsten, 2010, Johansen and Björkman, 2002). Product and production system are designed during the conceptual study. The product is developed, tested and refined by development of engineering prototypes. During pilot and pre-series productions the production system and product are tested, refined and adapted together. Finally during the production ramp-up remaining bugs are removed and expected production goals such as production volume, time and quality are reached (Johansen, 2005, Ulrich and Eppinger, 2012). Adler (1995) summarises the mechanisms for coordination of product introduction process into four categories based on the level of interaction between product design and production: standards, plans and schedules, mutual adjustment and teams. The level of 
novelty of the product and production systems defines the complexity the product introduction process (Adler, 1995, Tidd and Bodley, 2002, Almgren, 1999a).

\section{Low-Volume Manufacturing Industries}

Low-volume manufacturing industries are usually characterized by yearly production volumes between 20 to 500 products, high variety, complexity and customizability of products and full make-to-order production policy (Jina et al., 1997). In addition, new products are usually designed to be produced in the existing production systems to avoid high investment cost (Qudrat-Ullah et al., 2012). Therefore, the production systems in such industries are usually designed to offer high flexibility to be able to produce various products. Such flexibility is usually provided by using universal production equipment, highly-skilled workers, low level of automation and shared production resources among different products (Hill, 2000, Qudrat-Ullah et al., 2012). Such characteristics lead to lack of opportunities to test and refine product and production system and adapting them together due to few number of prototypes, limitations of pre-series productions and infeasibility of conventional production ramp-up (Javadi et al., 2013). In other word, opportunities to remove or mitigate disturbances at the start of production in low-volume manufacturing industries are limited in these industries. Therefore, identification of sources of disturbances and developing alternative solutions instead of applying the common approach of test and refinement during later phases of product introduction process is necessary in low-volume manufacturing industries.

\section{Method}

Since the empirical studies about the disturbances during the start of production in lowvolume manufacturing industries are limited, case study was selected as the research method. The first hand study of the subject of the research is expected to lead to increased understanding about it (Eisenhardt, 1989, Voss et al., 2002). Therefore, a multiple-case study design was selected to achieve the aim of this research.

Four product development projects were selected as the case studies. Two of the cases were studied in real-time which are hereafter called Project A and B. Project A was a small product modification project whereas Project B was a large product development project, i.e. a general modification of a product. Project A was followed for 11 months from October 2012 to September 2013. Project B was followed up for 14 months from October 2012 to January 2014. The two other cases were finished product development projects which were studied retrospectively which are hereafter called Project C and D. Project $\mathrm{C}$ was again a small project whereas project $\mathrm{D}$ was a large project. The studied events of Project $C$ and D had happened during respectively 11-month and 20-month periods.

Multiple sources were utilized for data gathering including semi-structured interviews and document studies. Informal conversations were also carried out mostly to complete the data about the background of the company and projects and other required data. Among the documents, a database which was used for registering and following up the disturbances related to the products during the production of new products was one of 
the main sources of data. In addition, people who were involved in the projects were interviewed to complete and verify the gathered data. In total, 29 semi-structured face to face interviews were conducted with people who were involved in different phases of the projects as well as the production engineers, production flow leaders and operators. Time of the interviews varied between 30 to 80 minutes. In Case A and B observation of the events of the projects were also used as a sources of data.

The intention with the multiple-case study design was to compare the disturbances at the start of the production of new products in different projects with different scopes. It also helped to study the effect of the changes in the coordination methods of product introduction process on the disturbances during the start of production in the real-time cases in comparison with the retrospective ones.

Deducted conclusions in all four case studies were validated through triangulating the collected data from different sources (Yin, 2013). Collected data from the cases was continuously recorded, summarized and transferred to a case study record and iteratively analyzed. The suggested process by Eisenhardt (1989) was utilized for analyzing the data by conducting within and then cross-case analyses and a comparison with the literature.

\section{$5 \quad$ Empirical Findings}

\subsection{The Company}

The company was a Swedish designer and manufacturer of underground construction and mining equipment. The company produced products with yearly production volume lower than 100 units in 4 main families. Each product has several variants with high level of customizability with many different options to fulfill the requirements of different customers and markets.

\subsection{Product Development Projects}

The goals of Project A and Project $\mathrm{C}$ were modifying a module of the products with minimum possible changes of other modules whereas Project B and Project D were started with the aim of general upgrade and modification of the products.

The general arrangements for the projects were similar. Each project was managed by a multidisciplinary team which consisted of a project manager, designers, production engineers, a product introduction project leader, and representatives from marketing and service departments. Due to high number of ongoing product development projects, all the project team members had to divide their time between different projects. Production engineers were also responsible for ongoing production activities.

All of the four products were planned to be assembled in the existing assembly lines and no new production system development were planned. As a results, minimizing the changes in the existing assembly lines were one of the goals in all of the projects.

Besides the above-mentioned similarities, the main difference between small and large projects regarding the product introduction process was that no prototype were planned for the small projects. The production of the upgraded products were started directly as normal commercial production. In contrary, the project plan of large products included 
production of one prototype and one product as pre-series production. In Case B the number of pre-series productions could be increased to four products depending on customer demands for the product.

In addition, some new coordination methods were introduced and used more formally in Case A and Case B in comparison with the retrospective cases, Case C and Case D. Design reviews were used to inform the production engineers and flow managers about the new features of the products and include their perspective in the product design. The production requirements were also gathered at the beginning of the new projects and were categorized and prioritized by the product introduction project leaders. These requirements were transferred in form of a list to the designers to be considered in the product design.

\subsection{Disturbances Related to the Product}

A considerable part of the studied disturbances in the problem reporting database were related to the lack of information or wrong information about connecting parts. Some example of connecting parts are nuts and bolts, cable sets and hydraulic hoses. In several instances, the information on the bill of material or drawings did not match the real product. Suggesting wrong sizes of screws and hoses, or wrong cable connections on the documents are some examples of these problems. In some cases, no information was given to the production about these parts and the operators had to find the parts by try and error or based on their experiences. This type of disturbances was categorized under missing/wrong information about connecting parts.

Another major share of disturbances was related to problems with assembling parts and components. In many occasions, the parts could not be assembled on the products due to non-conformity of parts interfaces, difficulty of accessing the place of the part on the product or the possibility of damaging other parts during the assembly work. This category of disturbances was named design for assembly disturbances.

Other types of disturbances ranged from non-functioning parts and components to the wrong or late delivery of them which were categorized as other. Figure 1 shows the share of each type of disturbances in the studied projects.

Fig. 1. Shares of each type of disturbances in each case

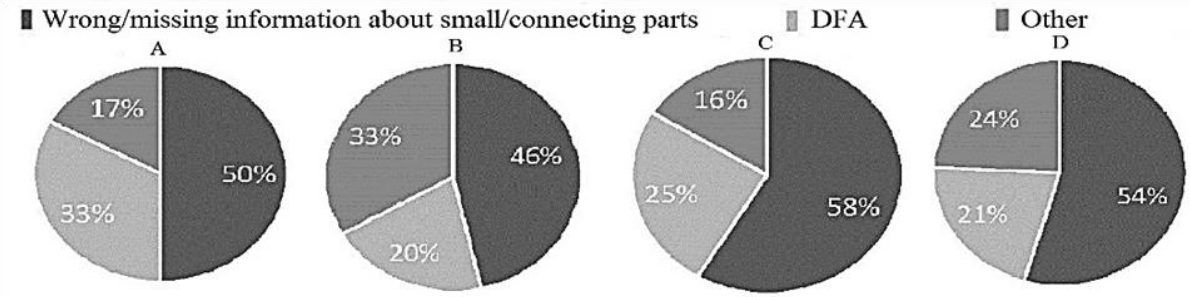

As Figure 1 shows, around half of the disturbances in all of the projects were caused by missing or wrong information about connecting parts. This share was reduced in the real-time cases (A and B) comparing to the retrospective ones ( $\mathrm{C}$ and $\mathrm{D})$. The disturbances caused by design for assembly problems had also considerable share varying from 20 to 33 percent of disturbances. However, these share was less in the large projects (B and D). 


\subsection{Disturbances Related to the Production System}

Disturbances related to the production system were mostly caused by late consideration of the required changes in the production system which were necessary to produce new products. Late delivery of the required tools and fixtures, overlooking the limitations of lifting and moving equipment and overestimating the available production capacity of the production system were some of the observed examples of these disturbances. In general, lack of considering the production requirements were repeatedly occurred in different sources data.

\section{$6 \quad$ Sources of Disturbances and Possible Solutions}

As the results suggest, lack of considering manufacturability of the products by neglecting design details and design for assembly criteria consist 70 to 80 percent of the product-related disturbances in all cases. Due to prioritizing functionality of the products over its manufacturability in the product development process, usually details of the product design were not considered sufficiently before handing over the product to the production. The limited shared resources among different product development projects are not sufficient to cover all the design priorities. Therefore, the problem of under-prioritizing manufacturability of the product was intensified. However, the newly implemented tools and methods for coordination of the product introduction process such as design reviews have reduced this kind of disturbances in both Case A and Case $\mathrm{B}$ compared to Case $\mathrm{C}$ and Case $\mathrm{D}$ by 8 percent. In addition, lack of opportunities to test and refine the products does not allow to remove such disturbances before handing over the product to production. Interestingly, the share of design for assembly disturbances were less in the large projects which had higher number of prototypes and consequently more opportunities were available to test and refine the products.

Another source of disturbance was late consideration of the required changes in the production system. Whereas under-prioritizing manufacturing requirements is also a usual problem in high volume production industries, it is intensified in low-volume manufacturing industries. Since no new production system is developed for new products in low-volume manufacturing industries and products are designed to be produced in the existing production system, the production system is usually considered "as is". Therefore, the required adjustments and changes in the production system is left to the very late stage of product introduction process if they are not totally ignored.

All in all, the characteristics of low-volume manufacturing industries intensifies the disturbances related to product and production system during the start of production mentioned by Surbier et al. (2013). Examples of such disturbances are lack of deign details, lack of considering manufacturability of products and late consideration of required changes in the production systems.

The results justify that utilizing more interactive product introduction coordination mechanisms such as design reviews suggested by Adler (1995) and Tidd and Bodley (2002) can reduce the disturbances during the start of production. However, the similarity of the types of disturbances and even their share in the disturbances in the realtime and retrospective cases suggests that the production of earlier similar products can 
be used as a very valuable source for learning and improvement in low-volume manufacturing industries. The similarity of the products and use of almost unchanged production systems increase the similarity of the product development projects to a high extent. Therefore, learning from similar problems in similar projects can be used as a compensation for lack of opportunities for test and refinement in the product introduction process in low-volume manufacturing industries. However, the knowledge about disturbances in production should be constantly gathered and shared with the product development teams. This knowledge should also be used efficiently by product development teams and especially by the product designers.

\section{Conclusions}

Regarding its aim, the paper provides an insight about the sources of disturbances during the start of production in low-volume manufacturing industries which are lack of opportunities for test and refinements, late consideration or ignoring required changes in production system and extensive focus on product functionality rather than its manufacturability. Furthermore, learning from production of similar previous products is identified as a valuable source for compensating lack of opportunities for test and refinement and mitigating other sources of disturbances. In this regard, the paper provides the practitioners in low-volume manufacturing industries with an insight to how to reduce disturbances during the start of production of new products by considering required activities in earlier phases of the product introduction process.

The main limitation of this research is excluding external variables of the product introduction process which could be investigated in future. In addition, a more detailed study of the solutions and facilitators could be another topic for further research.

\section{References}

1. ADLER, P. S. 1995. Interdepartmental interdependence and coordination: The case of the design/manufacturing interface. Organization Science, 6, 147-167.

2. ALMGREN, H. 1999a. Pilot Production and Manufacturing Start-up in the Automotive Industry. Principles for Improved Performance. Chalmers University of Technology.

3. ALMGREN, H. 1999b. Start-up of advanced manufacturing systems-a case study. Integrated Manufacturing Systems, 10, 126-136.

4. ALMGREN, H. 1999c. Towards a framework for analyzing efficiency during start-up:: An empirical investigation of a Swedish auto manufacturer. International journal of production economics, 60, 79-86.

5. ALMGREN, H. 2000. Pilot production and manufacturing start-up: the case of Volvo S80. International Journal of Production Research, 38, 4577-4588.

6. APILO, T. New product introduction in the electronics industry. 17th International Conference on Production Research, Blacksburg, USA, 2003.

7. BELlGRAN, M. \& SÄFSTEN, K. 2010. Production Development: Design and Operation of Production Systems, Springer London.

8. BERG, M. 2007. Factors affecting production ramp-up performance. Jönköping University.

9. CHRYSSOLOURIS, G. 2006. Manufacturing Systems: Theory and Practice, Springer Science+Business Media, Incorporated. 
10. EISENHARDT, K. M. 1989. Building theories from case study research. Academy of management review, 14, 532-550.

11. FJÄLLSTRÖM, S., SÄFSTEN, K., HARLIN, U. \& STAHRE, J. 2009. Information enabling production ramp-up. Journal of Manufacturing Technology Management, 20, 178196.

12. HENDRICKS, K. B. \& SINGHAL, V. R. 2008. The effect of product introduction delays on operating performance. Management Science, 54, 878-892.

13. HILL, T. 2000. Manufacturing Strategy: Text and Cases, Irwin/McGraw-Hill.

14. JAVADI, S., BRUCH, J., BELLGRAN, M. \& HALLEMARK, P. 2013. Challenges in the Industrialization Process of Low-Volume Production Systems. International Conference on Manufacturing Research 2013. Cranfield, United Kingdom: Cranfield university press.

15. JINA, J., BHATTACHARYA, A. K. \& WALTON, A. D. 1997. Applying lean principles for high product variety and low volumes: some issues and propositions. Logistics Information Management, 10, 5-13.

16. JOHANSEN, K. 2005. Collaborative Product Introduction within Extended Enterprises. Institutionen för konstruktions- och produktionsteknik.

17. JOHANSEN, K. \& BJÖRKMAN, M. 2002. Product introduction within extended enterprises. Proceedings of ISCE'02 International Symposium on Consumer Electronics, Ilmenau, Germany :

18. JUERGING, J. \& MILLING, P. M. Interdependencies of product development decisions and the production ramp-up. The 23rd International Conference of the System Dynamics Society, Boston, MA, USA, 2005.

19. MAFFIN, D. \& BRAIDEN, P. 2001. Manufacturing and supplier roles in product development. International journal of production economics, 69, 205-213.

20. NYHUIS, P. \& WINKLER, H. Development of a controlling system for the ramp-up of production systems. Proceedings of the international conference on competitive manufacturing, 2004. 4-6.

21. QUDRAT-ULLAH, H., SEONG, B. S. \& MILLS, B. L. 2012. Improving high variable-low volume operations: an exploration into the lean product development. International Journal of Technology Management, 57, 49-70.

22. RUFFLES, P. C. 2000. Improving the new product introduction process in manufacturing companies. International Journal of Manufacturing Technology and Management, 1, 1-19.

23. SURBIER, L., ALPAN, G. \& BLANCO, E. 2013. A comparative study on production ramp-up: state-of-the-art and new challenges. Production Planning \& Control, 1-23.

24. SÄFSTEN, K. \& ARESU, E. 2002. Assembly System Design and Evaluation of 15 Manufacturing Companies in Sweden. Manufactoring Systems, 31.

25. TERWIESCH, C. \& BOHN, R. 2001. Learning and process improvement during production ramp-up. International journal of production economics, 70, 1-19.

26. TERWIESCH, C., BOHN, R. \& CHEA, K. 2001. International product transfer and production ramp-up: a case study from the data storage industry. $R \& D$ Management, 31 , 435-451.

27. TIDD, J. \& BODLEY, K. 2002. The influence of project novelty on the new product development process. $R \& D$ Management, 32, 127-138.

28. ULRICH, K. T. \& EPPINGER, S. D. 2012. Product Design and Development, McGrawHill.

29. VOSS, C., TSIKRIKTSIS, N. \& FROHLICH, M. 2002. Case research in operations management. International Journal of Operations \& Production Management, 22, 195-219.

30. YIN, R. K. 2013. Case Study Research: Design and Methods, SAGE Publications. 